\title{
Legal Education in the Next Future
}

\section{Laura Bugatti ${ }^{1}$, University of Brescia, Italy}

\section{Abstract}

The legal profession is facing a new working environment marked by increasing globalisation, competition, technological advances and deregulation. Furthermore, the economic perspective imposed by the European Union - which leads us to consider lawyers as business as well as professionals - is having a profound impact on national regulations. Nobody would doubt that the intellectual professions have experienced a deep transformation whereas competition rules originally addressing more traditionally commercial ventures - have begun to penetrate in this different area. In this time of changes, the 'qualitative entry restrictions' - taking the form of minimum periods of education (and related educational standards), post-university vocational training and professional examinations - are maintaining a key role: ensuring that only practitioners with appropriate qualifications and competence can supply their legal services in the internal market. The first part of this paper is devoted to analysis of the evolution and changes involving legal education in European countries, adopting a comparative and historical perspective. Member states have the right to regulate professional services, and they have the primary responsibility of defining the framework in which professionals operate; therefore, regulation of legal education is, first and foremost, a national matter. Nevertheless, a historical overview of the different systems shows that

\footnotetext{
${ }^{1}$ Laura Bugatti, Ph.D., Research Fellow in Comparative Law, Law Department, University of Brescia (Italy). Email: laura.bugatti@unibs.it.
} 
Special Issue: European Network for Clinical Legal Education $6^{\text {th }}$ Conference

even if the starting points of the different traditions are very distant, sometimes even opposite, there are some common trends in the evolution that are going to create a harmonization in the field of legal education. In particular, every system is going to create a pathway to enter in the legal profession that ensures both academic studies and professional training, combining the theoretical knowledge with practical aspects.

The second part of the paper focuses on the new role embraced by the law schools, arguing that the new mission of law schools is, at least in part, to contribute to the creation of legal practitioners. In fact, it seems that the division between exclusively academic theoretical study and post-university vocational training is today unsustainable. Considering the law schools' new obligation to create both 'theoretic and practical' scholarship and the consequent shift towards more skills-based legal education, the second part of the paper will be devoted, in particular, to the analysis of the fundamental role that clinical legal education should play in this process of reform.

Summary: 1. European approach towards professionals: competition and better regulation; 2. Entry restrictions and their justification: ensuring the quality of legal services; 3. National legal educational models: a case of fragmentation?; 4. A comparative analysis: there is room for harmonization?; 5. Current criticisms and progressive trends in legal education; 6 . The role of legal clinics in the present and future educational system

\section{European approach towards professionals: competition and better regulation}


The legal profession is facing a new working environment marked by increasing globalisation, technological advances, competition and deregulation. ${ }^{2}$ Nobody would doubt that, in the last fifteen years, the European Union's approach towards the intellectual professions has constituted a leading force in the transformation of the legal market and profession in Europe. In particular, the European Union (EU), starting with the Lisbon Strategy, recognizing the crucial role played by professionals in the internal market, ${ }^{3}$ has begun to advocate the application of competition law even in the professional sector. ${ }^{4}$ In

\footnotetext{
${ }^{2}$ See also G. PAscuzzi, 'Verso l’Avvocatura e il Notariato', in B. PAsciuta \& L. LOSCHIAvo (eds.), La formazione del giurista. Contributi ad una riflessione (Roma TrePress, 2018), p 83: 'quattro fenomeni verificatisi negli ultimi decenni che stanno cambiando le professioni legali: la rivoluzione digitale, l'internazionalizzazione del lavoro, le istanze tese a 'liberalizzare le professioni', il favore con il quale il legislatore guarda alle alternative al contenzioso'.

${ }^{3}$ See Council of the European Union, European Council Presidency Conclusions, 22-23 March 2005, http://www.consilium.europa.eu/uedocs/cms_data/docs/pressdata/en/ec/84335.pdf; European Parliament, Followup to the Report on Competition in Professional Services, P6_TA(2006)0418, http://www.europarl.europa.eu/sides/getDoc.do?pubRef=-//EP//NONSGML+TA+P6-TA-20060418+0+DOC+PDF+V0//EN; European Parliament, Resolution on Market Regulations and Competition Rules for the Liberal Professions, 2004 OJ (C 91E) 126, http://www.europarl.europa.eu/sides/getDoc.do?pubRef=//EP//NONSGML+MOTION+B5-2003-0432+0+DOC+PDF+V0//EN; Communication from the Commission to the Council, the European Parliament, the European Economic and Social Committee and the Committee of the Regions, Professional Services-Scope for more reform - Follow-up to the Report on Competition in Professional Services, COM(2004) 83 of 9 February 2004 (SEC(2005) 1064): COM/2005/0405 final, http://eurlex.europa.eu/legal-content/EN/ALL/?uri=CELEX:52005DC0405; Commission Communication, Report on Competition in Professional Services, COM/2004/0083 final, http://eur-lex.europa.eu/legalcontent/EN/ALL/?uri=CELEX:52004DC0083.

${ }^{4}$ Concerning the European attempt to apply competition law to professional services, see: Report on the Economic Impact of Liberal Professionals in Different Member States, Invitation to Tender, Open Procedure, 2001; I. PATERSON, M. FinK \& A. OGUS, Economic Impact of Regulation in the Field of the Liberal Professions; European Commission, DG Competition, Stocktaking Exercise on Regulation of Professional Service: Overview of Regulation in the New EU Member States, COMP/D3/MK/D(2004),

http://ec.europa.eu/competition/sectors/professional_services/studies/overview_of_regulation_in_the_eu_professi ons.pdf; European Commission, DG Competition, Invitation to Comment: Regulation in Liberal Professions and Its Effects: Summary of Responses, 2003,

http://ec.europa.eu/competition/sectors/professional_services/studies/summary_of_consultation_responses.pdf; Commission Communication, Report on Competition in Professional Services; Commission Communication to the European Parliament, the Council, the European Economic and Social Committee and the Committee of the Regions, Upgrading the Single Market: More Opportunities for People and Business, COM(2015)550 final; see also the European Parliament's intervention 2015/2354(INI); Communication from the Commission to the European Parliament, the Council, the European Economic and Social Committee and the Committee of the Regions on Reform, Recommendations for Regulation in Professional Services, \{SWD(2016) 436 final $\}$, $\operatorname{COM}(2016) 820$ final,

http://ec.europa.eu/transparency/regdoc/?fuseaction=list\&coteId=1\&year=2016\&number=820\&version=ALL\&la nguage $=\mathrm{en}$; Communication from the Commission to the European Parliament, the Council, and the European Economic and Social Committee, Evaluating national regulations on access to profession, COM(2013)676, http://eur-lex.europa.eu/legal-content/EN/TXT/?uri=CELEX\%3A52013DC0676; European
} 
order to justify this economic approach, the professions have been classified by European jurisprudence and by Commission decisions as undertakings. In fact, the EU has adopted a broad definition of undertaking, encompassing any entity that carries out economic activity - consisting of providing services on the market - regardless of the particular status of the entity and the way in which it is financed. ${ }^{5}$ As a consequence, the peculiar attributes which characterize the intellectual professions (e.g. the intellectual, technical or specialized nature and the personal and direct basis on which the services are delivered), ${ }^{6}$ as well as the circumstance that they are classified as regulated profession in several member states, cannot be deemed as obstacles to classifying lawyers as business. In accordance with this innovative view, the EU Commission has introduced rigorous discussions about the justifications for professional national regulation, affecting both entry requirements and the exercise of the service, and member states have been required to revisit their professional

Commission, Proposal for a directive of the European Parliament and of the Council on a proportionality test before adoption of new regulation of professions, $\operatorname{COM(2016)~822,~https://eur-lex.europa.eu/legal-~}$ content/EN/TXT/?uri=COM:2016:0822:FIN; Directive (EU) 2018/958 of the European Parliament and of the Council of 28 June 2018 on a proportionality test before adoption of new regulation of professions, in GU L 173 9.7.2018, pp 25-34, https://eur-lex.europa.eu/legalcontent/EN/TXT/?toc=OJ\%3AL\%3A2018\%3A173\%3ATOC\&uri=uriserv\%3AOJ.L_.2018.173.01.0025.01.ENG. A similar trend towards deregulation was first endorsed in other jurisdictions, such as the US and Australia and, at the international level, by the Organisation for Economic Co-operation and Development (OECD). Cf. OECD, Competition Policy and the Professions, 1985; OECD, Competition in Professional Services, DAFFE/CLP(2000)2, http://www.oecd.org/regreform/sectors/1920231.pdf; OECD, DAF/COMP(2007)39. With regards to the US experience: Goldfarb v. State Bar of Virginia, 421 U.S. 773 (1975); Bates v. State Bar of Arizona, 433 U.S. 350 (1977); C.J. GAWLEY, 'Protecting Professionals from Competition: The Necessity of a Limited Antitrust Exemption for Professionals', in 47. S.D. L. Rev. (South Dakota Law Review) 2002, p 233; D. VÁZQuez ALBERT, 'Competition Law and Professional Practice', in 11. ILSA J. Int'l \& Comp. L. (ILSA Journal of International \& Comparative Law) 2005, p 555. More generally, see L.S. TERRY, 'The European Commission Project Regarding Competition in Professional Services', in Northwestern Journal of International Law \& Business 2009, p 1.

${ }^{5}$ Case C-41/90, Höfner ed Elser c. Macrotron, ECLI:EU:C:1991:161; Case 118/85, Commissione c. Italia, ECLI:EU:C:2002:36. L. SCUDIERO, La nozione di impresa nella giurisprudenza della Corte di Giustizia, in IV. Foro it. (Foro italiano) 1994, p 113; V. AfFERNI, 'La nozione di impresa comunitaria', in F. GALGANO, Trattato di diritto commerciale e diritto pubblico dell'economia, II (Padova: CEDAM 1978), p 134.

${ }^{6}$ 95/188/EC: Commission Decision of 30 January 1995 relating to a proceeding under Art. 85 of the EC Treaty (IV/33.686 - Coapi) OJ L 122, 02/06/1995, 0037-0050. 
rules, according to the so-called 'proportionality test', in order to maintain only restrictions that are justified on public interest grounds. The European call for 'better regulation' has revitalized the economic theories surrounding professional regulation, and the idea that some pro-competitive mechanisms can be implemented without detriment to the quality of professional services, even if in some cases the protection of clients and collectively as well as the good governance of the profession may impose the maintenance of some traditional restrictive rules. In fact, according to public interest theory, certain forms of regulation might be considered as a remedy for market failures arising from the particular features of the legal service markets. In particular, the lawyer-client relationship is often characterized by information asymmetry: ${ }^{7}$ the professional is always aware of the quality of the service being proposed or delivered; the client, however, has to rely on the professional's judgement due to his/her inability to ascertain the quality of the legal service and its correspondence to his/her legal needs. In fact, most professional services are considered as 'credence goods': as a result, it is often not possible for the client to evaluate the quality of the service, either before or after purchasing the service itself.

\footnotetext{
${ }^{7}$ B. ARRUNADA, 'The Economics of Notaries', in 3. Eur. J. Law Econ. (European Journal of Law and Economics) 1996, p 5; Robert G. EvANS \& Michael J. TREBILCOCK, Lawyers and the Consumer Interest (Toronto: Butterworths 1982); M. FAURE, J. Finsinger, J. SiEgERS \& R. VAN DEN BERGH (eds.), Regulation of Professions (Antwerpen: Maklu 1993; R. C.O. MAtTHEws, 'The Economics of Professional Ethics: Should the Professions Be More Like Businesses?', in 101. Econ. J. (Economic Journal) 1991, p 737; F. H. STEPHEN, 'The Market Failure Justification for the Regulation of Professional Service Markets and the Characteristics of Consumers' and R. VAN DEN BERGH, 'Towards Efficient Self-Regulation in Markets for Professional Services' in C.D. EhLERMANN and I. ATANASIU, European Competition Law Annual 2004: The Relationship Between Competition Law and the (Liberal) Professions (Oxford and Portland, Oregon: Hart Publishing 2006), p 143 \& p 155.
} 
As a consequence, the information asymmetry may give rise to quality deterioration resulting from adverse selection: ${ }^{8}$ if clients cannot judge the different value of professionals' services, their willingness to pay might be hampered; conversely, if lower fees become the 'average prices' of legal performance, the most qualified lawyers are encouraged to leave the market, as long as their behavioural traits and their efforts are not recognized and properly remunerated. Moreover, the information gap might lead to professionals' opportunistic behaviours, including the overvaluing of services in order to charge higher fees, the delivery of services at higher prices, as well as the provision of additional or totally unneeded services (the so-called 'moral hazard' problem). ${ }^{9}$

In addition, legal services serve public goals such as the good administration of justice and a well-functioning judicial system; for this reason, the quality of the legal performance might have a severe impact, not only on the single client situation, but also on society as a whole: on the one hand, legal services of insufficient quality might generate negative externalities, damaging both clients and third parties involved in the justice system; on the other hand, good-quality legal services generate positive externalities, contributing to ensure the protection of the client's rights, as well as to safeguard the correct administration

\footnotetext{
${ }^{8}$ G. AKERLOF, 'The Market for Lemons: Quality Uncertainty and the Market Mechanism', in Q. J. Econ (The Quarterly Journal of Economics) 1970, p 488; I. PATERSON, M. FINK \& A. OGUS, Economic Impact of Regulation in the Field of the Liberal Professions in Different Member States: Regulation of Professional Services (European Network Of Economic Policy Research Institutes Working Paper 52/February 2007), p 17, https://www.ceps.eu/system/files/book/1455.pdf; R. SPIEGLER, 'The Market for Quacks', in 76. Rev. Econ. Stud. (The Review of Economic Studies) 2006, p 1113; H. E. LELAND, 'Quacks, Lemons, and Licensing: A Theory of Minimum Quality Standards’, in 87. Journal of Political Economy 1979, p 1328.

${ }^{9}$ F. H. STEPHEN \& J. H. LOVE, 'Regulation of the Legal Profession' in B. BoucKaerT \& G. De Geest (eds.), Encyclopedia of Law and Economics, Volume III: The Regulation of Contracts (Cheltenham: Edward Elgar 2000), p 989; R. VAN DEN BERgh \& Y. MontAngIE, 'Competition in Professional Services Markets: Are Latin Notaries Different?', in 2. Journal of Competition Law \& Economics 2006, p (189) at 193-194; E. SHINNICK, F. BRUINSMA \& C. PARKER, 'Aspects of Regulatory Reform in the Legal Profession: Australia, Ireland and the Netherlands’, in 10. Int'l J. Legal Prof. (International Journal of the Legal Profession) 2003, p 237.
} 
of justice in the interest of the community. As a result, among the rationales of professional regulation, there is the need to avoid negative externalities while protecting the positive ones. ${ }^{10}$

The public interest explanations may constitute, therefore, the premise and the justification for the maintenance of a number of professional regulations at the national level. Nevertheless, not all the restrictive rules may be justified on the basis of the public interest arguments. ${ }^{11}$ The equilibrium between the preservation of traditional restrictive rules and the introduction of pro-competition mechanisms is not always easy to find.

\section{Entry restrictions and their justification: ensuring the quality of legal services}

Qualification and entry requirements (encompassing academic education and training as well as professional examinations) are a basic component of the regulation of lawyers. This is not surprising, considering the fact that the legal profession is classified as a regulated profession in almost all member states. ${ }^{12}$ Nevertheless, according to the Commission, with

\footnotetext{
${ }^{10}$ R.l N.M. GRAHAM, Legal Ethics: Theories, Cases, and Professional Regulation (3rd edn., Toronto: Emond Publishing 2014).

${ }^{11}$ Moreover, the 'public interest theories of regulation are challenged by private interest theories' (R. VAN DEN BERGH, Towards Better Regulation of the Legal Professions in the European Union (RILE Working Paper Series n. 2008/7 2007). Several economists are skeptical about the benefits of professional restrictive rules, arguing that professional regulation is used to serve mainly the interests of the legal profession and can be better explained by rent-seeking behavior, effective lobbying and regulatory capture. See J. A. KAY, 'The Forms of Regulation', in A. SELDON (ed.), Financial Regulation or Over-Regulation (London: Institute for Economic Affairs 1988), p 3342. The origin of this approach may be traced in Smith's view, who defined self-regulatory occupational groups as natural institutions for 'conspiracy against the public' and 'contrivance to raise prices'. See, also, A. SMITH, 'Of Wages and Profit in the Different Employments of Labour and

Stock, Part II: Inequalities Occasioned by the Policy of Europe', in A. SMITH, An Inquiry into the Nature and Causes of the Wealth of Nations (1776 - New York: MetaLibri 2007), p 97.

${ }^{12}$ As it is stated in Article 3.1., lett. a, 2005/36/CE, the regulated profession is a 'professional activity or group of professional activities, access to which, the pursuit of which, or one of the modes of pursuit of which is subject, directly or indirectly, by virtue of legislative, regulatory or administrative provisions to the possession of specific professional qualifications; in particular, the use of a professional title limited by legislative, regulatory or administrative provisions to holders of a given professional qualification shall constitute a mode of pursuit. Where the first sentence of this definition does not apply, a profession referred to in paragraph 2 shall be treated as a
} 
the recent initiatives aiming at giving an economic perspective to the regulation of the liberal professions, the justification of this kind of restriction has been questioned, in order to determine whether the qualitative entry restrictions are effectively justified in the name of public interest, consumer protection and quality of service or, contrariwise, may excessively restrict competition, promoting only lawyers' interests without yielding corresponding benefits to the society.

Even if empirical evidence on this aspect is limited and fragmentary, ${ }^{13}$ it has been argued that ex ante or input regulation could be a valuable tool to guarantee a high level of quality of legal services, in the clients' and the public's interest. When a profession is regulated, only professionals who meet certain requirements and possess the appropriate qualifications are allowed to offer their services in the market.

As has been noted elsewhere, 'Licensing thus attempts to influence the quality of the service before its provision (ex ante) and controls the input (mainly education and/or training) rather than the output. The underlying assumption is that there is a strong complementary relationship between investments in human capital (input) and the quality of the service provided.' ${ }^{14}$ As a consequence, when professionals who do not have the required qualifications and competence are excluded from the market, the overall quality of the legal services performed will of necessity be higher. For this reason, the input or ex ante regulation

\footnotetext{
regulated profession' (Directive 2005/36/EC of the European Parliament and of the Council of 7 September 2005 on the Recognition of Professional Qualifications, in Official Journal of the European Union, L 255, 30.9.2005, p 22-142).

${ }^{13}$ See F. H. STEPHEN \& J. H. LOVE, 'Regulation of the Legal Profession', cit., p 989; R. VAN DEN BeRGH \& Y. MonTANGIE, 'Competition in Professional Services Markets: Are Latin Notaries Different?', cit., p 193-194.

${ }^{14}$ T. HEREMANS, Professional Services in the EU Internal Market: Quality Regulation and Self-Regulation (Hart Publishing, 2012), spec. p 4.
} 
might be considered proportionate to the goal of ensuring professional quality: it is justified by public interest arguments, working both as a remedy for market failures ${ }^{15}$ and as a deterrence to moral hazard. ${ }^{16}$

\section{National legal educational models: a case of fragmentation?}

Member states have the right to regulate professional services and the primary responsibility of defining the framework in which professionals operate; therefore, the regulation of legal education is also, first and foremost, a national matter. For that reason, it is not surprising to find many differences among the national legal education models existing in Europe: each member state has its own education and training pathway to be followed in order to become a lawyer, and this pathway varies from one country to another. This heterogeneous situation can turn into a potential obstacle to having a common level of the quality of services offered in the internal market.

Among the main criteria differing from member state to member state, there are: a) the duration of the licensing procedure, with a range from around six to almost nine years (like in Slovenia); ${ }^{17}$ b) the intensity of the entry controls: some member states impose an 'incoming and outgoing' selection in order to become a lawyer. In particular, in order to start vocational training in law, graduates may be required to pass an exam at the end of

\footnotetext{
${ }^{15}$ See H. E. LELAND, 'Quacks, Lemons, and Licensing: A Theory of Minimum Quality Standards', cit.

${ }^{16}$ C. SHAPIRO, 'Investment, Moral Hazard, and Occupational Licensing', 53. The Review of Economic Studies 1986, p 843.

${ }^{17}$ Art. 25 of the Bar Act, The Official Gazette of the Republic of Slovenia, No. 18-817/1993, dated 9 April 1993, Official Gazette of the Republic of Slovenia, No. 24-1465/1996, 10 May 1996; Decision by the Constitutional Court, Official Gazette of the Republic of Slovenia, No. 24-1455/2001, 5 April 2001, Official Gazette of the Republic of Slovenia, No. 54/08, 2 June 2008, Official Gazette of the Republic of Slovenia, No. 35/09, 8 May 2009.
} 
their university studies, and a second exam has to be taken at the end of the traineeship for becoming a lawyer. For example, a dual bar exam is required by the German regulation, ${ }^{18}$ as well as by the Polish one. ${ }^{19}$ On the other side, some other member states, like Italy, impose one single entry selection, i.e. an exam at the end of the traineeship. In some cases the examination is taken before the end of the training (this is, for example, the case of Belgian regulation). In some jurisdictions, periodic exams during the training are compulsory (like in Poland). In some other member states, before or during the professional traineeship, additional training, vocational courses, notably on matters not covered at all in the university curriculum, such as professional ethics, are required; c) the connection with the educational system imposed for other legal professions: the English and the German systems might be seen as the two extremes - on one side, the UK imposes separate educational and professional paths to the two branches of the legal profession, i.e. barrister and solicitors; on the other side, the German model requires a common education for all the traditional juridical professions in order to create the so-called Einheitsjurist, a jurist who is able to work as a judge as well as a lawyer; d) the importance reserved to the continuous professional development: although it is mandatory in the majority of member states, in some of them it remains on voluntary basis. ${ }^{20}$

\footnotetext{
${ }^{18}$ For more information concerning the licensing procedure in Germany, see Bundesrechtsanwaltsordnung (BRAO), arts. 4-17; see also the Gesetz zur Reform der Juristenausbildung vom 11.07.2002, Bundesgesetzblatt 2002 Teil I Nr. 48, 2592; J. RIEDEL, 'The Reform of Legal Education in Germany', in 0. Eur. J. Legal Educ. (European Journal of Legal Education) 2001, p (3) at 3-10; A. KEILMANN, 'The Einheitsjurist: A German Phenomenon', in 7. Germ. Law jour. (German Law Journal) 2006, p (293) at 297-298.

${ }^{19}$ For more information concerning the Polish formal requirement to be admitted to the Bar, see A. BoDNAR \& D. ByCHAwSKA, The Legal Profession in Poland, 2009, https://www.osce.org/odihr/36308?download=true.

${ }^{20}$ This is the case, for example, in the Czech Republic, Greece, Malta, Slovakia, Slovenia and Spain.
} 
This brief excursus on the main traits of the actual national educational models leads us to the conclusion that it is not possible to infer the existence of a common European model of delivering legal education and training. However, a historical comparative analysis can offer a different point of view on this topic that allows us to see an increasing convergence in legal education in Europe, especially as regards the continental civil law tradition.

\section{A comparative analysis: is there room for harmonization?}

Legal education in continental Europe has long since been associated with university education. ${ }^{21}$ The Italian tradition might be taken as a paradigm. Legal education has its origin in the Middle Ages, when the first university was founded in Bologna. The didactic method forged by the School of Bologna in 1088 was designed for legal scholars who needed to find and teach the 'right' solutions. ${ }^{22}$ Law was taught as a model or structure, completely cut off from any practical consideration - such as the needs of the client or the means of resolving disputes. Such a conception has influenced both the nature of the teaching of law, giving it a theory-based and conceptual character, and the essence of European continental law itself.

During the Napoleonic period this framework shifted a little in favour of the professionalization of a 'legal class' and 'a new socialization based upon competency' ${ }^{23}$

\footnotetext{
21 'L'università fu la base comune del poderoso ceto internazionale dei giuristi': P. G. MONATERI \& A. SOMMA, 'Il modello di civil law', in A. Procida Mirabelli Di LAURo (ed.), Sistemi Giuridici Comparati (Torino, 2009), p 33.

${ }^{22}$ See D. RENÉ \& J. SPINOSI CAMILle, I grandi sistemi giuridici contemporanei (5 ed, CEDAM 2004), p 33: 'The Law, as the Moral, is a "Sollen" (what we should do) and not a "Sein" (what we do in practice)'.

${ }^{23}$ See M. MALATESTA, 'L'Ordine professionale, ovvero l'espansione del paradigma avvocatizio', in 3. Parolechiave 1995, p 270. See also S. PARINI VINCENTI, 'Ad Auxilium Vocatus. Studi sul praticantato da Napoleone alla Legge professionale del 1874: l'esperienza normativa', in A. PADOA SCHIOPPA (ed.), Avvocati e
} 
During the eighteenth century, training courses and examinations were gradually established. Furthermore, successive law reforms introduced post-university traineeships and exams as requirements for entry to the legal professions. At the end of the nineteenth century, the legal education system started to be articulated in the law degree, a period of training followed by a final test. It has been said that 'the application of the law to practical cases requires a very particular ability that can only be gained through practice' ${ }^{24}$

As a consequence, in continental Europe, and in the civil law tradition, despite the specifically academic roots, we have seen over the centuries the emergence and consolidation of a process of professionalization that has ensured that professional bodies retain ultimate regulatory control over access to professional titles.

Contrary to the continental tradition, English legal education and training was born as a product of the legal profession and the Inns of Court. ${ }^{25}$ In the beginning, university legal education in England was almost inexistent. As a matter of fact, the modern legal education system in England and Wales has been shaped in part by a series of reforms that began only by the mid-nineteenth century. From the mid-twentieth century, some government reports ${ }^{26}$

avvocatura nell'Italia dell'Ottocento (Bologna, 2009), p 59 ff.

${ }^{24}$ See A. BIANCHI, Sull'esercizio delle professioni di avvocato e procuratore. Testo e commento della legge 8 giugno 1874 (Torino, 1886), p 99.

${ }^{25}$ Concerning the evolution of legal education in UK, see: C. N. GREGORY, 'A Movement in English Legal Education', in 10 Harvard Law Review 1897, p 418 ff.; R. M. STEIN, 'The Path of Legal Education from Edward I to Langdell: A History of Insular Reaction', in 57. Chi. Kent L. Rev. 1981, p 429; A. BoON \& J. WEBB, 'Legal Education and Training in England and Wales: Back to the Future?', in 58. Journal of Legal Education 2008, p 79; N. PiCARDi and R. MARTino (eds.), L'educazione giuridica (Bari, 2008) and G. MorLEY, 'Legal Education in England and Wales’, in N. PICARDI \& R. MARTINO (eds.), L'educazione giuridica, cit., 365 ss.

${ }^{26}$ See, in particular: Report of the Legal Education Committee, Cmd. 4663 (London, HMSO, 1934) ('Atkin Committee'); Report of the Committee Appointed by the Prime Minister under the Chairmanship of Lord Robbins, Cmnd. 2154 (London, HMSO, 1963) ('Robbins Report'); Report of the Committee on Legal Education, Cmnd. 4595 (London, HMSO, 1971) ('Ormrod Report’); Royal Commission on Legal Services, Final Report, Cm. 7648 (London, HMSO, 1979) ('Benson Report'); A Time for Change: Report of the Committee on the Future of the Legal Profession (London, General Council of the Bar/The Law Society, 1988) ('Marre Committee'); Lord Chancellor’s Advisory Committee on Legal Education and Conduct, First Report on Legal Education and Training (London, 
started to criticize the state of legal education, warning of the poor standards in legal education, recognizing the inefficiency of the system, the need for reform of legal education and the possibility of introducing an entry method that would evaluate not only the practical training but also the university studies. In 1971, the Ormrod report ${ }^{27}$ advocated the introduction of a three-stage model of legal education: an academic stage, a professional stage and a continuing stage. The normal academic stage has become the law degree, or its equivalent. In the wake of the Ormrod report, the law degree was confirmed as the standard mode of entry into the profession also by the reports that followed ${ }^{28}$ (almost until the solicitors qualifying exam (SQE) announced reform - see infra).

As a consequence, in the common law tradition, we have witnessed an opposite evolution compared to the civil law tradition, with the emergence and consolidation of law as an academic discipline, despite its origins being essentially anchored to the professional world. The historical evolution of the different macro-traditions of legal education gives evidence that even if the starting points are very distant, even opposite, there are some common trends in the evolution that harmonize European legal education. In particular, every system has created over the centuries a pathway to enter the legal profession that ensures both the academic education and the professional training/practical experience, combining the theoretical knowledge with practical aspects. Moreover, these profound changes of the

\footnotetext{
ACLEC, 1996) ('ACLEC’); Review of the Regulatory Framework for Legal Services in England and Wales, 2004 ('Clementi Report'); Legal Education and Training Review, The Future of Legal Services Education and Training Regulation in England and Wales, June 2013, http://www.letr.org.uk/the-report.

${ }^{27}$ Report of the Committee on Legal Education, cit.

${ }^{28}$ See Legal Education and Training Review, The Future of Legal Services Education and Training Regulation in England and Wales, cit., p xiv: 'A number of recommendations are made in respect of the Qualifying Law Degree (QLD) and Graduate Diploma in Law (GDL). These continue to provide an important pathway into the legal services sector for a range of authorised persons, and thus constitute an important foundation for professional training.'
} 
educational systems have led, in civil law as well as in the common law tradition, to the construction of different stages of education and training which have created distinct spheres of influence for the different stakeholders. Usually law schools, as liberal institutions, retain as primary goals the promotion and production of legal culture, the transmission of legal knowledge and the development of students' analytical and critical reasoning skills. ${ }^{29}$ On the other hand, bar associations have the mission to equip graduates with the understanding and acquisition of practical legal skills and competence, and potentially legal ethics, throughout vocational stages, traineeship and/or exam(s).

\section{Current criticisms and progressive trends in legal education}

Nevertheless, as history explains, the relationship among different stakeholders is not a stable one, and also, the three-stage model - university degree / vocational stage and training/exam(s) - is just an artificial division. What is more constant are the critics of the legal educational system, the rethinking of approaches to teaching and learning law, in theory and in practice, and ways to test knowledge, skills and competence, also taking into consideration the ongoing changes involving the legal profession. ${ }^{30}$ As recently noted,

\footnotetext{
${ }^{29}$ Even if the freedom of universities sometimes encountered some constraints, as in the case of the several core subjects of the English GDL imposed by the professional bodies.

${ }^{30}$ See S. CASSESE, 'Legal Education under Fire', in 1. European Review of Private Law (Eur. rev. priv. law.) 2017, p (143) at 144 and 145: the author considering the French model underlined that: 'Teaching methods and materials are criticized as being too dogmatic and doctrinal, closed to the social sciences, and oriented towards the study of law as set out in books rather than to the study of law in action' (C. JAMIN, 'L'enseignement du droit à Sciences Po: autour de la polémique suscitée par l'arreté du 21 mars 2007', in Jurisprudence: Revue critique 2010, p 125 ff.; C. JAmin, La cuisine du droit: L'École de Droit de Sciences Po: une expérimentation française (Paris: L.G.D.J. 2012); M. VoGLIOTTI, 'L’urgence de la question pédagogique pour le droit postmoderne', 72. Revue Interdisciplinaire d'Études Juridiques (RIEJ) 2014, p 73 ff.; C. JAMIN \& M. XIFARAS, 'De la vocation des facultés de droit (françaises) de notre temps pour la science et l'enseignement', RIEJ 2014, p 107 ff.; C. JAMIN \& M. XIFARAS, 'Retour sur la "critique intellectuelle” des facultés de droit', 4. La Semaine Juridique (SJ) 2015, p 155 ff.; R. SEFTON-GREEN, 'Démoulages’: Du carcan de l'enseignement du droit vers une éducation juridique, Société de législation comparée, Paris 2015); referring to the situation of legal education in Germany affirmed that: 'German experts too complain that doctrinal subjects are central in legal education, that legal education does not focus sufficiently on the application, active creation and implementation of the law, that law teaching does not pay enough attention to the European legal order and to the comparative approach, that academic reflection
} 
'Legal education has come under fire from all quarters, almost everywhere in the world. Legal education is criticized in many different contexts, by a variety of actors, and for a great number of reasons. ${ }^{31}$

This sense of dissatisfaction with the way in which legal education is structured and delivered has led in England and Wales to the shocking announcement by the Solicitors Regulation Authority (hereafter SRA) that it is going to revise the pathway to qualify as a solicitor. Currently, would-be solicitors are required to complete a qualifying law degree (QLD) or law conversion course at university (GDL), a one-year vocational course, the Legal Practice Course (LPC) and, finally, two years of supervised training (training contract) in order to qualify as a solicitor. The three-stage structure is similar to the educational model designed for the would-be barrister: graduates (with a QLD or a GDL) are required to join one of the Inns of Court, undertake one-year full-time course, the Bar Professional Training Course, be called to the Bar and complete a recognized period of training under the supervision of an experienced barrister, the Pupillage. ${ }^{32}$

prevails over practice-oriented studies, and that there is not enough interdisciplinary cooperation' (Wissenschaftsrat, Prospects of Legal Scholarship in Germany. Current Situation, Analyses, Recommendations, Hamburg 9 November 2012). See also A. Von BOGDANDY, 'Le sfide della scienza giuridica nello spazio giuridico europeo,' 2. Il diritto dell'Unione Europea 2012, p 22). Concerning the critics of the English system, the author, referring to the LETR report, recalled as main reasons for critique: 'insufficient assurance of a consistent quality of outcomes and standards of assessment; limits on the acceptable forms of professional training; knowledge and skills gaps in respect of legal values and professional ethics, communication, management skills and equality and diversity awareness; limits on horizontal and vertical mobility; increasing cost barriers affecting access to academic, professional and workplace training, particularly for solicitors and barristers in noncommercial practice; and the existence of limitations on the capacity for coherent evidence-based policymaking' (Legal Education and Training Review, The Future of Legal Services Education and Training Regulation in England and Wales, cit.).

${ }^{31}$ See S. CASSESE, 'Legal Education under Fire’, cit., p 143.

${ }^{32}$ New training requirements for the Bar are expected to come into effect in early 2019 (subject to Legal Services Board approval); nevertheless, the three components of education and training (the academic component, the vocational component and the work-based learning component) will be maintained, even if delivered through one of four approved training pathways; for more information on the Future Bar Training (FBT), see https://www.barstandardsboard.org.uk/qualifying-as-a-barrister/future-requirements/; Bar Standards Board, 'BSB 
Nevertheless, the SRA has announced that from 2021, as part of a new approach to qualifying as a solicitor in England and Wales, it will abandon the qualifying law degree (QLD) and the Legal Practice Course (LPC), in favour of a centralized examinations system, the Solicitors Qualifying Exam (SQE). ${ }^{33}$ In particular, the announced SQE reform will require would-be solicitors to undergo a centralized exam regulated by the SRA, consisting of two parts: the first one, testing legal knowledge through multiple-choice questions; the second one, consisting of skills assessments. The candidates will also have to undertake 24 months of practical training (qualifying work experience - QWE).

The radical changes announced by the SRA, which undermined the validity of the traditional three-stage model, are expected to have a profound effect on the entire English

Policy Statement on Bar Training' (2017) www.barstandardsboard.org.uk/media/1825162/032317_fbt__policy_statement_version_for_publication.pdf

For more information concerning the Legal education System in England and Wales: A. Boon \& J. WEBB, 'Legal Education and Training in England and Wales: Back to the Future?', cit., p 79; D. NITTI, 'La professione forense in Inghilterra', in A. BERLINGUER, La professione forense. Modelli a Confronto (Milano, 2008), p 97 ff.; C. GILLIGAN, La formazione dell'avvocato in Inghilterra e Galles: qualità professionale, deontologia e mercato, in G. ALPA and A. MARIANI MARINI (eds.), La formazione dell'avvocato in Europa (Pisa, 2009), p 113 ff; B. NASCIMBENE, La professione forense nell'unione europea (Milano 2010), p 233 ff; R. M. STEIN, The Path of Legal Education from Edward I to Langdell: a History of Insular Reaction, cit., p 429; D. NITTI, 'Come cambia la professione forense inglese: spunti per una comparazione', in Contratto e Impresa/Europa 2006, p 280 ff.; R. CRESPI, 'Le professioni legali in Inghilterra e Galles da Edoardo I al Court and Legal Service Act', in Le carte e la Storia, 2005, p 126; P. PURPIDGE, 'La formazione professionale in Inghilterra e nel Galles', in Rass. Forense 1995, p 399.

33 See SRA, Statement of Solicitors Competence (March 2015), https://www.sra.org.uk/solicitors/competencestatement.page; SRA, Training for Tomorrow: Assessing Competence, Consultation Paper (7 December 2015), https://www.sra.org.uk/sra/consultations/t4t-assessing-competence.page; SRA, A New Route to Qualification: The Solicitors Qualifying Examination, Consultation Paper (25 April 2017), https://www.sra.org.uk/sra/consultations/solicitors-qualifying-examination.page; SRA, A New Route to Qualification: New Regulations, Consultation Paper (15 November 2017), https://www.sra.org.uk/sra/consultations/newregulations.page.

For comments on the SRA initiative, see R. FLETCHER, 'Legal education and proposed regulation of the legal profession in England and Wales: a transformation or a tragedy?’, in 50. The Law Teacher 2016, p 371; E. HALL, 'Notes on the SRA report of the consultation on the Solicitors Qualifying Exam: "Comment is free, but facts are sacred”', in 51. The Law Teacher 2017, p 364; E. FRY \& R. WAKEFORD, 'Can we really have confidence in a centralised Solicitors Qualifying Exam? The example of the Qualified Lawyers Transfer Scheme', in 51. The Law Teacher 2017, p 98; C. JAMES \& J. KOO, 'The EU law "core” module: surviving the perfect storm of Brexit and the SQE', in 52. The Law Teacher 2018, p 68; J. GIBBONS, 'Policy recontextualisation: the proposed introduction of a multiple-choice test for the entry-level assessment of the legal knowledge of prospective solicitors in England and Wales, and the potential effect on university-level legal education', in 24 International Journal of the Legal Profession 2017, p 227; M. DAVIES, 'Changes to the training of English and Welsh lawyers: implications for the future of university law schools' in 52. The Law Teacher 2018, p 100. 
model of legal education. Because a law degree will not be mandatory in order to sit the SQE, the only choice for the law schools will be between opting in or opting out of SQE preparation. They could, in other words, keep a distance from the interest of the legal profession and provide a more liberal and theoretical education; or - on the contrary - they might move further on, in the direction of professional and vocational courses, in order to reach the standards required to embrace the SQE. ${ }^{34}$ Both choices have potentially significant and obvious consequences. The replacement pathway to qualify as a solicitor in England and Wales offered by the SRA, which totally underestimates the role of university and pushes towards a pure apprenticeship model, seems to remove the English system from the harmonized model of legal education described before. ${ }^{35}$

In continental Europe, the criticisms concerning the current educational system, as well as the innovations involving the professions in the recent years, are still generating some significant changes (even if the impact is not comparable with the English one).

Over the past century, despite the growing professionalization of the legal class and the increased importance of the bar association in the legal educational process, continental law

\footnotetext{
34 'With regard to the demise of QLDs and GDLs, for law schools which choose to continue to offer degree courses or similar which prepare students for the SQE, this will be the first time for most that they have faced an externally devised syllabus and externally set and marked assessments with regard to this aspect of their activity. For those institutions which choose to opt out and, perhaps, use the introduction of the SQE as an opportunity to move their law degrees away from their current professional accreditation focus, this will be the first time in decades that they have faced a significant market test to determine how many students will choose to study law without a professional accreditation attractor': M. DAVIES, 'Changes to the training of English and Welsh lawyers: implications for the future of university law schools’, cit., p (100) at 101.

${ }^{35}$ Even if the law degree maintains its validity with reference to the pathway to qualify as a barrister in England and Wales, it is well known that the percentage of graduates who become barristers is very low compared to the percentage of the students who qualify as solicitors. In 2017, the total barristers in practice were 16,435 (See Bar Standards Board, Practising barrister statistics, https://www.barstandardsboard.org.uk/media-centre/research-andstatistics/statistics/practising-barrister-statistics/); while 'at 31 July 2017, there were 139,624 solicitors with practising certificates (PC) and 181,968 individuals in total on the roll of solicitors' (see The Law Society, Annual Statistics Report 2017, https://www.lawsociety.org.uk/support-services/research-trends/annual-statistics-report2017/).
} 
schools, reaffirming their own role, have continued to uphold as their exclusive aims the promotion and production of legal culture, maintaining in conformity with such objectives an essentially theoretic teaching methodology. ${ }^{36}$ Nevertheless, a number of harsh criticisms levelled against academia consistently over the past 100 years are signs of a disconnect between the law school and the wider society. Is there a need for an education that insists on keeping theory and practice apart?

Such criticism is still echoed today in university classrooms and, although it does not appear sufficiently supported, in an 'atmosphere of dated paralysis' ${ }^{37}$ that has perhaps always characterized academia and other institutions under pressure to change, it seems to dictate current (and increasingly noticeable) progressive trends. Recently, in fact there have been attempts directed at integrating practical components into the curricula, such as some law school initiatives targeted at introducing legal skills courses and legal clinics. ${ }^{38}$ Whilst far

\footnotetext{
${ }^{36}$ See M. Cappelletti, J. H. Merryman \& J. M. Perillo, The Italian Legal System: An Introduction (Stanford, 1967), p 89: the authors, referring to Italian academia, affirmed that law schools 'are not concerned with techniques of problem-solving, but with the inculcation of fundamental concepts and principles'.

${ }^{37}$ See L. CAIANI, Problemi dell'Università italiana (Milano, 1955), p 7.

${ }^{38}$ In relation to the recent development of Clinical Legal Education in Western Europe, defined as "the last holdout in the worldwide acceptance of clinical legal education” (R. WILSON, 'Western Europe: Last Holdout in the Worldwide Acceptance of Clinical Legal Education - Part I/II', in 10. German Law Journal 2009, pp 823846), see C. BARTOLI, 'Legal clinics in Europe: for a commitment of higher education in social justice', in 1. Diritto e Questioni Pubbliche 2016; Id., 'The Italian legal clinics movement: Data and prospects', in 2. International Journal of Clinical Legal Education 2015, p 22; D. BLAZQUEZ-MARTIN, 'The Bologna Process and the Future of Clinical Education in Europe: A View from Spain’ in F.S. BLOCH (ed.), The Global Clinical Movement. Educating Lawyers for Social Justice (Oxford, 2011) 121; H. OLÀsOLO, 'Legal Clinics in Continental Western Europe: The Approach of the Utrecht Legal Clinic on Conflict, Human Rights, and International Justice', in 104. American Society of International Law 2010, p 98; Jan-Gero Alexander HANNEMANN \& F. CZERNICKI, 'Eine rechtsvergleichende Analyse der "Clinical Legal Education” - studentische Rechtsberatung in Polen und Deutschland', in 2. German Journal of Legal Education 2015, p 27. With regards to the Brescia Legal Clinic, see C. АмАто, 'Developing strategies for academic and financial sustainability: the Brescia legal clinic's experience', in E. PoILlot (ed.), L'enseignement clinic du droit: Expériences Croisées et perspective pratique (Luxembourg: Larcier, 2014). In relation to the recent development of clinical legal education in Central and Eastern Europe, see, above all, M. BERBEC-ROSTAS, A. GUTNIKOV \& B. MAMYSLOSWSKA-GABRYSIAK, 'Clinical Legal Education in Central and Eastern Europe: Selected Case Studies' in F.S. Bloch (ed.), The Global Clinical Movement. Educating Lawyers for Social Justice, cit., p 53.
} 
from the norm, such developments are on the increase across continental Europe. The creation of the clinic network ENCLE (European Network for Clinical Legal Education) evidences that. ${ }^{39}$ One may speculate as to the driving forces, but almost certainly this includes the aim of developing a student's knowledge and practical skills, both of which are required of a professional. ${ }^{40}$

\section{The role of clinical legal education in the present and future educational system}

In spite of cultural differences among different national models of legal education on the continent, the specific requirements imposed by the national law curricula and the different relationship between universities and the relevant professional bodies, a new harmonized trend is emerging in continental Europe: a common and renewed approach to legal education begs a rethink of the curriculum content, embracing knowledge, skills and values. $^{41}$

In this latest process of reform, the mission of law schools and the mission of post-university training associations (bar associations, professional schools and in some instances universities), while maintaining their own specificities, tend to converge: they each provide

\footnotetext{
${ }^{39}$ See: www.encle.org.

${ }^{40}$ The legal studies in several civil law jurisdictions have come under criticism thus their exclusive theoretical nature and the need for more practical elements in the curricula has been suggested; consequently, they have had similar legal studies' development, even maintaining their traditional and historical features; see, as an example, the Czech Republic experience: 'The Czech Republic, which can be perceived as a bridge between Western and Eastern Europe and shares many common features with countries from both parts of Europe. The legal education was traditionally very theoretical, with occasional discussions about the lack of practical elements. In the 1990s, there were several clinical projects taking place at different law schools, but none of them was particularly successful (...). I have the impression that the recent intensive development of legal clinics in the Czech Republic (and also in other European countries) derives from understanding that traditional legal education was inefficient and did not focus enough on skills and professional values': M. TOMOSZEK, 'The Growth of Legal Clinics in Europe - Faith and Hope, or Evidence and Hard Work?', in 21. International Journal of Clinical Legal Education 2014, p 99.

41 'Sapere, Saper fare e Saper essere: è questa la trilogia sulla quale si struttura il mestiere dell'avvocato': G. PAscuZzI, 'How to Become Lawyers and Able to Do So: Teaching the Ethics of the Legal Profession through Narrative’, Research Paper no. 11, 2012, http://eprints.biblio.unitn.it/4003/1/11._Pascuzzi.pdf.
} 
knowledge, skills, competences, ability for a defined market; students are required to master theoretical legal concepts as well as to meet standards of technical competency, in order to understand law in its operational context and aspire to be future ethical and competent professionals.

Experiential learning, in general, and clinical legal education, in particular, may constitute valuable tools for tackling the challenges and meet the needs of the current and renewed educational context.

Firstly, clinical legal education is a pedagogical means that permits the application of theory to real or realistic (in case of simulation) cases in order to understand the law in practice: students gain the opportunity to discover the law in its operational context, to discuss the meaning of the rules, to question the needs of reform as well as to appreciate the role of the law in society. ${ }^{42}$

Moreover, the clinical method provides the understanding and acquisition of lawyering skills (such as fact-finding, clients interviewing, legal drafting, ADR methods and so on) as well as of the development of professional responsibility and wider ethical values. Students are required to work as legal professionals; in other words, they have to act with competence and ability in the interest of the client and become aware of the social relevance of their role, acting accordingly, assuming responsibility for their behaviour and facing the consequences of their actions.

\footnotetext{
${ }^{42}$ C. AMATO, 'Experiential Learning from the Continental Viewpoint: If the Cap Fits...', in R. Grimes (ed.), Rethinking Legal Education Under the Civil and Common Law: A Road Map for Constructive Change (Routledge, 2017).
} 
Furthermore, unlike what happens in real life, universities are a 'place where the learning can be guided, can be structured, can be taught rather than merely learned'. ${ }^{43}$ Law schools represent a privileged context in which, under the competent supervision of academics and professionals, students can experience the power of reflective learning. Students are required to move between action and reflection, visit and revisit the experience, thinking about what has been done, deepening the reasons underpinning actions, wondering how else they could have acted, trying to act differently if needed and appreciate the new consequences. In this way, the reflection also serves as a serious practice of learning.

Secondly, clinical legal education constitutes a unique opportunity to build links with the practicing profession and empower the dialogue between law schools and professional bar associations. For instance, the University of Brescia's Law Clinic ${ }^{44}$ (the clinic in which I have the privilege of working) has created over the years a strong collaboration with the local bar association and lawyers: the local bar association is permanently involved in the organization of the course and present in the academic committee; moreover, approximately ten local lawyers with significant professional experience are regularly involved in the program as students' supervisors as well as experts in specific fields (such as legal ethics and ADR).

Finally, through clinical legal education, academia draws closer to society: law schools, through a creative reinterpretation of their role, open their doors to vulnerable individuals

\footnotetext{
43 J. E. Moliterno, 'Experience and Legal Ethics Teaching’, Faculty Publications. Paper 930, 2001, http://scholarship.law.wm.edu/facpubs/930.

${ }^{44}$ For more information concerning the Brescia model, see C. Amato, 'Developing Strategies for Academic and Financial Sustainability: The Brescia Legal Clinic’s Experience’, cit., p $141 \mathrm{ff}$.
} 
and excluded communities by providing legal services. Universities, through legal clinics, have the possibility to tackle unmet legal needs, helping the most vulnerable, who often have very limited access to legal services for financial, logistical or cultural reasons and who have more limited possibilities for enforcing or defending their rights. Therefore, clinical legal education represents a valuable tool to enhance access to justice and to foster social change. The law schools, taking advantage of the clinical model of education, gain the chance, through the pursuit of their primary educational mission, to advance social justice and, ultimately, to give the public more confidence in the solicitors' profession. 